\"Me halutaan käsikirjoittaa toinen maailma" - metamoderni utooppisuus Emma Puikkosen Eurooppalaisissa unissa ja Riikka Pulkkisen Parhaassa mahdollisessa maailmassa

Kasimir Sandbacka 
K irjallisuudentutkimuksessa on pitkään puhuttu postmopostmodernismin seuraajaksi ehdotetuista käsitteistä on metamodernismi, jonka keskeisimpiä teoreetikkoja ovat olleet taiteentutkijat Robin van den Akker ja Timotheus Vermeulen. Heidän mukaansa kapitalismi on muun muassa tietoyhteiskunnan kehityksen myötä siirtynyt uudenlaiseen globaaliin vaiheeseen, jonka kulttuuristen ilmentymien käsittelyyn postmodernismin teoriat eivät enää riitä (Vermeulen \& van den Akker 2015, 56). Metamodernismi huojuu modernin toiveikkuuden ja postmodernin epäluulon välillä (Vermeulen \& van den Akker 2010). Epistemologisesti metamodernismi on "ikään kuin" -ajattelua ja ontologisesti "välissä olemista": siinä "hyväksytään epävarmuus ja muutos" ja pidättäydytään lopullisista valinnoista vastakohtien välillä (Hallila 2019, 159160; Vermeulen \& van den Akker 2010). Totuuteen suhtaudutaan ikään kuin se olisi saavutettavissa: itse pyrkimys sitä kohti on arvokasta, vaikkei sitä koskaan tavoitetakaan (Vermeulen \& van den Akker 2010). Tämän logiikan mukaisesti metamodernismissa tarkastellaan uudelleen monia käsitteitä, joihin postmodernismissa suhtauduttiin epäluulolla, kuten historiaa, suuria kertomuksia ja toimijuutta (Vermeulen \& van den Akker 2015, 55).

Keskeisimpiä näistä "mahdottomista mahdollisuuksista" on Vermeulenin ja van den Akkerin $(2015,57)$ mukaan utopia, joka postmodernin epäluulon aikakauden jälkeen on tehnyt läntiseen kulttuuriin paluuta "trooppina, yksilöllisenä haluna tai kollektiivisena fantasiana". Utooppisen halun ja toivon herättäminen on keskeistä, ei niinkään ihanneyhteiskunnan esittely: utopia on työkalu, jonka avulla reaalista maailmaa voi tarkastella ja pohtia vaihtoehtoisia mahdollisuuksia. Kun postmodernismissa suuriin kertomuksiin suhtauduttiin epäillen ja utooppista ajattelua saatettiin pitää turhanpäiväisenä haihatteluna tai vaarallisena totalitarismina, metamodernismissa moderni utopia palaa muuttuneessa muodossa. Postmodernismin skepsistä ei ole unohdettu vaan se asetetaan vuoropuheluun modernin edistysuskon kanssa. Metamodernismi huojuu postmodernin apatian ja modernin totalitarismin ääripäiden välillä sortumatta kumpaankaan. Postmoderneja ilmaisukeinoja ei hylätä vaan käytetään itsetietoisesti postmodernin epäluulon eetoksen ylittämiseen. (Vermeulen \& van den Akker 2010; 2015, 62, 65.) Samansuuntaisia kehityskulkuja hahmottanut Irmtraud Huber mainitsee postmodernin jälkeisen fiktion keskeisiksi piirteiksi muun muassa postmodernien kerrontatapojen käyttämisen uusilla tavoilla ja "strategisen nai[i]viuden" tai"itsekriittisen optimismin" - uskon siihen, että fiktio voi tavoittaa ja välittää maailmasta jotain merkityksellistä postmodernismin esittämistä varauksista huolimatta (Huber 2014, 32-33; Malmio 2019, 184-185).

Suomalaisen kirjallisuuden suhde postmodernismiin on ollut monella tapaa omintakeinen. Postmoderni avantgardismi jäi lyhyeksi vaiheeksi 1980-luvulla, mutta 1990-luvulla postmodernismin piirteitä sulautui vähemmän radikaalissa muodossa osaksi valtavirtaisempaa kirjallisuutta (Hägg 2000; Hallila 2013, 
86-86; ks. myös Malmio 2019, 205). Suomalainen nykykirjallisuus ei kuitenkaan ponnista yksinomaan kansallisesta traditiosta, vaan käy enenevässä määrin vuoropuhelua kansainvälisen kirjallisuuden kanssa. Kirjallinen elämä on 2000-luvulla alkanut yhä rohkeammin ylittää kansallisia kehyksiään eli ylirajaistua (Nissilä 2016, 67), eikä nykyromaani ole enää yhtä tiivisti kiinnittynyt kansallis-realistiseen perinteeseen kuin ennen (Hallila 2013, 85). Tämä seuraa kansainvälistä kehitystä, jossa nykyromaanit syntyvät globaalissa tilassa sen sijaan, että jatkaisivat itsenäistä kansallista traditiota (ks. Boxall 2017, 7). Kansallisella traditiolla on edelleen merkitys nykykirjallisuudessa, mutta se on jännitteisessä suhteessa globaalistumiseen. Suomalaisen nykykirjallisuuden keskeisiä piirteitä ovat dialogi menneen ja nykyisen välillä sekä intensiivisempi kurkottelu vieraisiin ympäristöihin ja kulttuureihin (Niemi 2019, 67, 69).

Tässä artikkelissa käsittelemäni romaanit, Emma Puikkosen Eurooppalaiset unet (2016, tästä eteenpäin EU) ja Riikka Pulkkisen Paras mahdollinen maailma (2016, tästä eteenpäin PMM), edustavat tätä kehitystä: ne käyvät vuoropuhelua historian kanssa ja käsittelevät Suomen rajat ylittäviä aiheita. Teosten avulla voidaan hahmottaa laajemminkin suomalaista nykykirjallisuutta globaalissa tilassa - tai ainakin osoittaa metamodernismin mahdollistamia tulkintastrategioita. Tarkastelen erityisesti metamodernia utooppisuutta osoittamalla, kuinka romaanit koettavat ylittää postmodernin ironisen eetoksen ja kuinka aikamme utopianvastaisuus ja toisaalta tarve utooppiselle ajattelulle tematisoituvat romaanien tavassa käsitellä eurooppalaista lähihistoriaa. Dystopiaa suomalaisessa kirjallisuudessa on tutkittu viime aikoina verraten paljon (ks. esim. Isomaa \& Lahtinen [toim.] 2017), mutta utopia on jäänyt vähemmälle huomiolle. Metamodernia teoriaa ei myöskään ole juuri sovellettu suomalaisessa kirjallisuudentutkimuksessa, ja kansainvälisestikin keskustelu metamodernista utooppisuudesta kirjallisuudessa on vasta aluillaan. Aloitan analyysini tarkastelemalla romaanien maailmojen rajojen hämärtämistä ja huojumista modernistisen ja postmodernistisen dominantin välillä. Sitten tarkastelen utopian tematisoitumista romaaneissa. Lopuksi pohdin sitä, kuinka teoksissa tuodaan esiin metamodernia kirjoittamisen eetosta ja sen tehtävää utooppisen ajattelun herättämisessä.

\section{Huojuvat maailmat}

Brian McHalen (2003) mukaan modernistisen ja postmodernistisen kirjallisuuden keskeisin ero on se, että modernismi on ensisijaisesti kiinnostunut epistemologisista kysymyksistä ja postmodernismi ontologisista. Modernismi on siis ensisijaisesti kiinnostunut siitä, mitä ja miten voimme tietää maailmasta, kun taas postmodernismi keskittyy erilaisten vaihtoehtoisten, rinnakkaisten tai päällekkäisten maailmojen mahdollisuuteen. McHale selventää argumenttiaan toteamalla, että modernistisen proosan populaari sisarlaji on salapoliisi- 
kertomus ja postmodernistisen tieteiskertomus. (Mt., 9-11, 59.) Van den Akker ja Vermeulen eivät pohdi metamodernismia McHalen dominanttien valossa (Helle 2019, 55), vaan pohjaavat teoriansa etenkin Fredric Jamesonin (1992) käsitykseen postmodernismista myöhäiskapitalismin kulttuurisena logiikkana (ks. Vermeulen \& van den Akker 2015, 55; Sandbacka 2017, 3-4). Huberin mukaan postmodernismin jälkeinen kirjallisuus on jättänyt sekä epistemologisen että ontologisen painotuksen taakseen ja keskittyy ensisijaisesti fiktioon ja kommunikaatioon liittyviin eettisiin ja pragmaattisiin kysymyksiin. Postmoderni epäluulo pyritään ylittämään uskomalla kommunikaation mahdollisuuteen, joka perustuu jaettuun käsitykseen kommunikaation konventioista ja rajoituksista. (Huber 2014, 28, 40.)

Voidaan kuitenkin kysyä, miten tällainen yhteisymmärrys asettuu historialliseen suhteeseen aiempien dominanttien kanssa. Tarkoitan tällä sitä, ettei usko kommunikaation mahdollisuuteen voi perustua ontologisten ja epistemologisten kysymysten ohittamiseen vaan siihen, että ne hahmotetaan uudella tavalla. Esitänkin, että metamodernismi huojuu epistemologisen ja ontologisen dominantin välillä ja että mahdollisuus kommunikaation avautuu välitilassa, jossa ei sitouduta lopullisiin totuuksiin muttei myöskään äärimmäiseen relativismiin. Siispä tarkastelen ontologisen ja epistemologisen dominantin välistä huojuntaa Eurooppalaisissa unissa ja Parhaassa mahdollisessa maailmassa ennen kuin siirryn käsittelemään romaanien utooppisuutta ja metamodernin kirjoittamisen eetosta.

Puikkosen ja Pulkkisen romaaneissa maailmat ja aikatasot liukuvat toisiinsa ja maailmojen rajarikkomukset näyttäytyvät yliluonnollisina ilmiöinä: näkyinä, aaveina ja riivauksina. McHalen mukaan postmodernille kirjallisuudelle on tyypillistä, että yliluonnolliset tapahtumat eivät hämmästytä henkilöhahmoja. Hän kutsuu tätä vastakohtaisen latteuden retoriikaksi (rhetoric of contrastive banality). (McHale 2003, 76.) Eurooppalaisissa unissa ja Parhaassa mahdollisessa maailmassa yliluonnollinen ei banalisoidu vaan näyttäytyy henkilöhahmoille ihmeellisenä tai on palautettavissa psykologiseksi ilmiöksi, kuten uneksi tai harhaksi. Ontologiset rajanylitykset kuitenkin palvelevat myös epistemologista intressiä: ne ovat näkymiä historiaan ja täydentävät henkilöhahmojen käsitystä menneisyydestä. ${ }^{1}$

Eurooppalaisiset unet koostuu yhdeksästä toisiinsa kytkeytyvästä episodista, joiden tapahtumat ajoittuvat vuosien 1980 ja 2027 välille. Tapahtumapaikat ovat eri puolella Eurooppaa ja henkilöhahmot eri-ikäisiä eurooppalaisia eri ammateista ja sosiaaliluokista. Jotkut henkilöhahmot esiintyvät useammassa episodissa, mutta varsinaista päähenkilöä ei ole. Romaanissa sivutaan lukuisia historiallisia tapahtumia, kuten Solidaarisuus-liikkeen muodostumista ja Gdanskin telakkalakkoja vuonna 1980, Berliinin muurin murtumista (1989) ja Irakin sotaa vastustaneita mielenosoituksia (2003). Joitakin näistä tapahtumista käsitellään romaanin kerronnassa suoraan, mutta toiset ilmenevät henkilöhahmojen näkyinä. Juuri uninäyt, "eurooppalaiset unet", rikkovat kerronnan ontologiset 
rajat, sillä aina ei ole selvää, että niissä on kyse vain subjektiivisista, psykologisesti selitettävistä ilmiöistä.

Euroopan yhdentymisen historia tematisoituu jo Eurooppalaisten unien ensimmäisessä luvussa. Romaani alkaa kuvauksella Gdanskin telakkalakoista. Siitä siirrytään Belgian ja Saksan rajalle, jolla tšekkoslovakialainen kuormaautonkuljettaja Toma odottaa rajamuodollisuuksien selviämistä. Tilanne muistuttaa liikkumisen rajoituksista ennen Euroopan unionia ja Schengenin sopimusta. Odotellessaan Toma tapaa ruotsalaisen reppureissaajan, Johanneksen, ja ottaa tämän kyytiin. He lähtevät ajamaan kohti Espanjaa ja kuulevat radiosta Puolan lakoista. Toma ihailee lakkolaisten utooppista toiveikkuutta, sitä, "että ihmiset edes kärpäsenpaskan mittaisen hetken uskovat että voivat liikuttaa tulevaisuuttaan" (EU, 18).

Jo nimi Eurooppalaiset unet viittaa uneksimiseen ja unelmointiin, joita on pidetty tärkeinä utooppisen halun ilmenemismuotoina (ks. Levitas 2011, 138-139). Todellisuuden rajoja uhmaava uninäky onkin romaanin keskeinen postmoderni kerrontakeino. Useimmat keskushenkilöistä näkevät jonkin näyn, jonka kautta he todistavat tapahtumia toisaalla Euroopassa tai näkevät toteutumattomia historiallisia mahdollisuuksia. Ensimmäisen näyn näkevät Toma ja Johannes Pyreneet alittavassa tunnelissa. Yhtäkkiä valot pimenevät ja tunnelista kantautuu ääniä. Miehet näkevät, kuinka "[i]hmisjoukkiot marssivat maan alla pitkin kirkkaasti valaistua tunnelia, joka risteää heidän pimeän tunnelinsa kanssa" (EU, 24). Risteävälle tunnelille ei ole rationaalista selitystä ja Toma toteaakin: "Erittäin kuule hyvä että oot kyydissä. Muuten mä oisin aatellut että mä oon hullu." (EU, 25.) Arkinen maailma limittyy selittämättömästi tuntemattoman maailman kanssa. Ontologisten repeämien kautta henkilöt saavat tietoa historiallisista muutoksista tai toivoa muutoksen mahdollisuuteen. Unet rikkovat todellisuuden rajat, mutta auttavat samalla ymmärtämään todellisuutta. Ne siis huojuvat ontologisen ja epistemologisen dominantin välillä. Tunnelille ja romaanin muille näyille saadaan eräänlainen ontologinen selitys vasta romaanin lopussa.

Myös Paras mahdollinen maailma toimii usealla aikatasolla. Pääjuoni kuvaa, kuinka Aurelia-nimisen näyttelijän lapsuuden trauma kohoaa tietoisuuden pintaan näytelmän harjoitusten aikana. Toinen keskeinen näkökulma on Aurelian äidin minä-kerrontana esitetty pyrkimys löytää uudelleen yhteys tyttäreensä ja 1970- ja 1980-luvulle ajoittuvat muistot, joissa sivutaan Saksan demokraattisen tasavallan (DDR) historiaa ja Saksojen yhdistymistä. Kolmas juonne on Aurelian kanssa näytelmää työstävän unkarilaislähtöisen ohjaajan Joachimin oman traumaattisen menneisyyden käsittely.

Pulkkisen romaanissa ontologiset rajanylitykset ilmenevät kummitteluina tai riivauksina, joissa toiset, eri ajassa eläneet subjektit tunkeutuvat Aurelian tietoisuuteen ja huojuttavat hänen käsitystään minuudestaan: "Aurelia tietää, ettei hän itse ajattele näitä ajatuksia. Hänessä ajatellaan. Tai jopa: hänelle ajatellaan." (PMM, 76.) Näyttelijäntyö altistaa Aurelian tällaisille kokemuksille, ja hän on 


\section{Romaanien mukaan utooppista ajattelua tarvitaan, jotta nykyiselle järjestelmälle voidaan kuvitella vaihtoehtoja.}

nuoresta asti leikitellyt erilaisilla identiteeteillä. Yhtälttä tuntemukset voidaan tulkita Aurelian kuvitelmiksi, jolloin romaanin ontologia säilyttää realistisuutensa. Toisaalta tuntemukset huojuvat intersubjektiivisuuden kynnyksellä. Kun Aurelia ja ohjaaja Joachim rakastelevat, fokalisaatio siirtyy hetkeksi Joachimiin, joka "näkee Aurelian sisällä hahmon joka pyytää häntä seuraamaan itseään" (PMM, 173). Hahmo johdattaa sekä Joachimia että Aureliaa historiallisen tiedon äärelle. Romaani värähtelee ontologisen ja epistemologisen dominantin välillä. Ontologisesti se herättää lukijan kysymään, millainen on romaanin maailma, jossa tietoisuudet limittyvät ajan yli ja mitä henkilöiden kokemat "hahmot" ja "olennot" (PMM, 173) ovat. Epistemologisesti se kohdistaa huomion historiaan: mitä menneisyydessä on tapahtunut ja mitä siitä voi tietää?

Romaanissa paljastuu vähitellen, että Aurelia ja Joachim ovat kokeneet samanlaisen lapsuudentrauman: molemmat ovat menettäneet lapsena siskon. Joachimin sisko Frieda surmattiin Balatonjärvellä elokuussa 1989 - pari kuukautta ennen kuin Aurelia ja hänen kaksoissiskonsa Annabella syntyivät Berliinin muurin murtuessa. Annabella puolestaan hukkui yhdentyneessä Berliinissä 1992. Ontologisesti romaani vihjaa jopa jonkinlaiseen sielunvaellukseen: siihen, että Friedan kuoleman läheisyys Aurelian ja Annabellan syntymän kanssa on kytkenyt heidät toisiinsa. Epistemologisesti romaani taas viittaa historian materiaalisuuteen ja intersubjektiivisen tiedon mahdollisuuteen: menneisyydessä on tosia tapahtumia, jotka vaikuttavat nykyhetkeen ja joista voidaan saada jaettua tietoa. Näin Aurelian ja Joachimin tuntemukset voidaan tulkita torjutun trauman pulpahteluksi tietoisuuteen ja uudeksi, merkityksellisemmäksi suhteeksi historiaan. He tunnistavat traumansa toisissaan ja ymmärtävät menneisyydestä yhdessä enemmän kuin yksin kykenisivät.

Eurooppalaisten unien tapa limittää aikatasoja ja vaihtoehtoisia todellisuuksia on sukua rinnakoinnille (sideshadowing ${ }^{2}$ ) eli vaihtoehtoisten nykyisyyksien tai tulevaisuuksien esittämiselle, joka Alison Gibbonsin (2020, 8-9) mukaan on ominaista metamodernin kirjallisuuden ajallisuudelle. Rinnakointi voi laajentaa "mahdollisen tajuamme" ja herättää meidät näkemään, kuinka erilaiset tulevaisuudet ovat valintojemme tulosta (Meretoja 2018, 9). Eurooppalaisissa unissa 
rinnakointi toteutuu etenkin uninäkyjen kautta. Selkein esimerkki on Karinin uninäky. Syntyjään itäsaksalainen Karin sairastui parivuotiaana tuberkuloosiin, ja hänen isänsä vei hänet Länsi-Berliiniin hoitoon. Hoidon aikana Berliini jaettiin kahtia, ja Karinin äiti jäi itään loukkuun. Berliinin muurin murruttua äiti palaa länteen ja Karin käy hänen kanssaan katsomassa sairaalaa, jossa Karinia hoidettiin. Karin ja hänen äitinsä näkevät yhteisen unen, jossa äiti on nuorta tytärtään vastassa sairaalan ulkopuolella ojentaen "kätensä yli kolmenkymmenen vuoden, yli ei-kenenkään-maan, viisumivirkailijoiden ja piikkilanka-aidan" (EU, 63). Näyssä toteutumaton, toivottu menneisyys rinnastetaan toteutuneen, traagisen menneisyyden kanssa. Rinnastus korostaa tehtyjen päätösten merkitystä: kuinka erilaiset poliittiset päätökset voivat johtaa erilaisiin tulevaisuuksiin. Parhaassa mahdollisessa maailmassa rinnakointia ei samalla tavalla esiinny, mutta siinäkin vaihtoehtoisten tulevaisuuksien hahmottaminen on keskiössä, kuten seuraavassa, utopiaa käsittelevässä luvussa käy ilmi.

\section{Utopian paluu}

Ruth Levitasin mukaan kirjallisuudentutkimuksessa on viime vuosikymmeninä kiinnitetty utopiaan huomiota ennen kaikkea prosessina tai muotona, ei niinkään kirjallisuuden sisältönä. Tämä on mahdollistanut hienostuneita tulkintoja, joissa teksteistä on onnistuttu löytämään sellaista utooppista ja dystooppista ylijäämää, joka ei kenties ole kirjailijan tietoisen intention mukaista. Kääntöpuolena on se, että utopian funktio jää pelkän vallitsevan yhteiskunnan kritisoinnin tasolle. Levitas pohtiikin, onko utopioiden kirjoittaminen todella muuttanut muotoaan vai luemmeko vain utopioita myöhäismodernina aikana uudella, avoimuutta, tilapäisyyttä ja refleksiivisyyttä korostavalla tavalla. (Levitas 2014, 112-113.) Vermeulen ja van den Akker $(2015,65)$ kuvaavat metamodernia utopiaa peiliksi, jonka kautta voi tutkia vaihtoehtoisia mahdollisuuksia tässä ja muissa maailmoissa. Se ei siis rajoitu pelkkään vallitsevan yhteiskunnan kritiikkiin, vaan siinä voi nähdä piirteitä Levitasin (2014, 18-19) peräänkuuluttamasta utopiasta metodina - kokonaisvaltaisena tapana hahmottaa taloudellisia, yhteiskunnallisia, eksistentiaalisia ja ekologisia yhteyksiä. Tässä utooppinen kirjallisuus on ymmärrettävä tietyissä historiallisissa olosuhteissa syntynyttä utopian lajia laajemmin: kirjallisuudessa voi olla utooppinen ulottuvuus tai se voi käsitellä utopiaa, vaikkei sisälläkään ihanneyhteiskunnan konkreettista kuvausta (vrt. Levitas 2011, 5).

Parhaan mahdollisen maailman utooppisuus henkilöityy etenkin Aurelian isään Theodoriin, joka nuoruudessaan oli Aurelian äidin mukaan "utoopikko vailla vertaa" (PMM, 54). Hänen henkilöhistoriansa jännittyy utooppisuuden ja antiutooppisuuden välille. Theodor eli Theo on vauraaseen porvarissukuun syntynyt älykkö, joka monen 1970-luvun opiskelijan tapaan osallistuu radikaaliin poliittiseen liikehdintään. Hän opiskelee DDR:ssä, mutta ei pohjimmiltaan usko 
kommunistiseen järjestelmään: vasemmistoradikalismi on performanssi, jolla hän kapinoi perheensä porvarillisia arvoja vastaan. 1980-luvun lopussa hän liikkuukin DDR:n toisinajattelijapiireissä ja 1990-luvun lopulla tekee väitöskirjan fukuyamalaisittain "liberalismista rauhanprojektina historian lopun jälkeisessä maailmassa" (PMM, 319). Neuvostoliiton romahdus sai yhdysvaltalaisen politiikan tutkija Francis Fukuyaman (1992) esittämään teesinsä historian lopusta: koska liberaalille demokratialle ja markkinataloudelle ei ollut enää varteenotettavia kilpailijoita, historia - ymmärrettynä erilaisten yhteiskuntajärjestelmien kilpailuksi - oli päättynyt.

Tunnetuimpia postmodernismin kiteytyksiä on Jean-François Lyotardin (1985) näkemys postmodernismista suurten metakertomusten epäilynä. Sen on katsottu kohdistuvan erityisesti marxilaiseen edistysajatteluun (McGuigan 2006, 14). Levitasin mukaan viime vuosikymmenten poliittinen kulttuuri on ollut laajemminkin antiutooppista. Epäluulo utopioita kohtaan juontaa juurensa kylmän sodan vastakkainasetteluihin sekä kommunismin romahtamiseen vuodesta 1989 alkaen ja sitä seuranneeseen kapitalismin voitonriemuun. Utooppisen ajattelun väistämättömänä poliittisena lopputulemana on nähty 1900-lukulainen totalitarismi kommunistisessa tai fasistisessa muodossaan. (Levitas 2014, 7.)

Yhtäältä Theon väitöskirja asettuu siis osaksi aikansa vallitsevaa antiutooppista konsensusta. Toisaalta Theon ajatuksessa liberalismista rauhanprojektina on itsessään toiveikkuutta, jos ei suoranaista utooppisuutta. Tämän vuosituhannen poliittiset kehityskulut ovat osoittaneet Fukuyaman diagnoosin ja Theon toiveikkuuden ennenaikaisiksi. Theo käsittää vuoden 2001 terrori-iskut World Trade Centeriin käännekohdaksi. Pari päivää niiden jälkeen hän toteaa Aurelian äidille: "Tajuatko että kaikki, aivan kaikki on muuttunut. Tornien mukana romahti koko idea siitä, mitä minä olen kehitellyt. Kaikki pitää ajatella uusiksi." (PMM, 333.) Romaanin nykyhetkessä Theo makaa sairaskohtauksen jälkeen tajuttomana sairaalassa, eikä lukija saa suoraan tietää, mitä hän kuolinvuoteellaan ajattelee. Sen sijaan lukijalle tarjotaan Aurelian kuvittelema keskustelu isänsä kanssa, jossa Theo toteaa: "Historia ei loppunut vaan alkoi alusta banaalimpana kuin kukaan osasi kuvitella" (PMM, 324). Theon kirjoittama maailma ei koskaan toteutunut.

Jo nimellään Paras mahdollinen maailma kutsuu pohtimaan utopiaa. Teoksessaan Essais de Theodicée (1710, "Esseitä teodikeasta") Gottfried Wilhelm Leibniz pohtii, kuinka Jumala voi olla hyvä ja kaikkivoipa, vaikka maailmassa on pahuutta. Theon nimikin viittaa tähän teodikeana tunnettuun teologiseen pahan ongelmaan. Leibniz tarjoaa teodikeaan ratkaisuksi sitä, että elämme "parhaassa mahdollisessa maailmassa", joka on rationaalisesti kuviteltavissa. Mikä tahansa parannus jollain osa-alueella johtaisi merkittävämpään huonontumiseen toisella alueella. (Leibniz 1996, 228.) Elämme Leibnizin mukaan siis eräänlaisessa ideaalissa kosmisessa kompromississa, jonka Jumala hyvyydessään ja viisaudessaan on tasapainottanut. 
Teoksen sisällä "paras mahdollinen maailma" viittaa leikkiin, jota Aurelia lapsena tapasi leikkiä isänsä kanssa. Leikissä "piti keksiä lakeja sille miten yhteinen elämä olisi miellyttävämpää" (PMM, 328), toisin sanoen harjoittaa utooppista ajattelua. Postmodernismin viitekehyksessä näin tendenssinomainen utopian tematisointi houkuttelisi ironiseen tulkintaan, jossa utooppinen metakertomus asettuisi kritiikin kohteeksi. Aurelian kuvittelemassa keskustelussa Theo ei kuitenkaan ole sarkastinen vaan kannustaa vilpittömyyteen. Hänelle WTC-iskujen terroristit "olivat vakavuuden arkkitehteja", jotka "omivat ylevän ja tosissaan olemisen" (PMM, 324). Peter Boxallin (2013, 127) mukaan 2000-luvun romaanin kiinnostus syyskuun 11. päivän iskuihin voi kertoa pyrkimyksestä herätä postmodernista poliittis-eettisestä narkoosista ja palata "radikaalin näkemisen historian" pariin. ${ }^{3}$ Theon suurin pelko onkin, etteivät ihmiset herää tuosta narkoosista ja opi näkemään postmodernin simulacrumin ${ }^{4}$ taakse - "etteivät ihmiset koskaan tajunneet olevansa kopioita jostakin suuresta ja paremmasta” (PMM, 332). Hän pelkää, että lakkaamme tavoittelemasta parasta mahdollista maailmaa, jonka halju kopio maailmamme hänen mukaansa on. Jamesonin (1982, 156; 2007, 142) mukaan utooppisen kirjallisuuden keskeinen tehtävä on pohtia utopian kuvittelemisen ja representoimisen vaikeutta. Utopian representoimattomuus tiedostetaan metamodernissa eetoksessa: utopia on alati vetäytyvä horisontti, jota tavoitellaan sen saavuttamattomuudesta huolimatta (ks. Vermeulen \& van den Akker 2010; 2015, 66).

Myös Eurooppalaisten unien ensimmäisessä luvussa utooppinen halu ilmenee pelon kautta: Toman suurimmassa pelossa "mennään tulevaisuuteen samalla sapluunalla, ilman että kukaan ihan todella ehtii miettiä että mihin tämä johtaa" (EU, 14). Utooppinen halu ei ole Tomalle pelkkää toivemaailmasta unelmointia vaan pyrkimystä paremman tulevaisuuden järkiperäiseen kuvitteluun ja tavoitteluun. Toman matkakumppani Johannes sen sijaan on postmoderni subjekti, joka on omaksunut ajatuksen historian lopusta: "[M]ä toivon että kaikki pysyisi samana, juuri nyt on hyvä, mä voisin olla tien päällä koko loppuelämäni, jutella ihmisten kanssa, katsoa kasvoja ja kuunnella ajatuksia ja vaan tulla tästä kaikesta humalaan" (EU, 14). Miesten eroavat näkemykset liittyvät myös siihen, että he ovat kasvaneet erilaisissa eurooppalaisissa ympäristöissä: Johannes vauraassa, puolueettomassa, länteen kuuluvassa Ruotsissa ja Toma totalitaristisen Neuvostoliiton satelliittivaltiossa Tšekkoslovakiassa, jonka demokratiapyrkimykset tukahdutettiin väkivalloin 1968.

Kiinnostavaa onkin, että Johannes on näistä kahdesta se, josta myöhemmin sattuman oikusta tulee eräänlainen näkijä: hän saa halvaannuttuaan yliluonnollisen kyvyn nähdä "miljoona samanaikaista hetkeä" (EU, 38). Yhtäkkiä postmodernilta, individualistiselta nomadisubjektilta katoaa liikkumisen mahdollisuus ja hän on pakotettu näkemään historia intersubjektiivisena tapahtumien verkostona, joka ei pysy samana vaan on jatkuvassa liikkeessä. Berliinin muurin murtumisen näkeminen muistuttaa häntä Toman utooppisesta halusta: "Muistan miehen jonka kyytiin joskus liftasin, miten hän iloitsi mielenosoituksesta 
jossain Itä-Euroopassa, muistan että hänen liikutuksensa oli hellyttävää, nyt ehkä ymmärrän” (EU, 40). Johanneksen postmoderni subjektius ylitetään postmodernin kerronnallisen keinon kautta. Hänen yliluonnollinen kykynsä rikkoo realistisen ontologian rajoja, mutta seurauksena ei ole tiedollinen relativismi ja historian tarinallistuminen, vaan uudelleen virinnyt mahdollisuus empatiaan ja intersubjektiiviseen käsitykseen historiasta.

\section{Maailman kirjoittaminen}

Postmodernismin keskiössä on ollut vakiintuneiden totuuksien kyseenalaistaminen itserefleksiivisen ironian keinoin (Huber 2014, 5). Lee Konstantinoun (2017) mukaan siirtymä kohti postmodernismin jälkeistä ilmaisua englanninkielisessä proosassa on merkittäviltä osin ollut juuri vallitsevaa ironista eetosta vastaan kirjoittamista. ${ }^{5}$ "Postironikkojen" tarkoituksena ei ole ollut unohtaa postmodernin ironian kriittisyyttä vaan päästä yli ironian "häiritsevimmistä ulottuvuuksista". Postmodernin kirjallisuuden keinot, kuten antirealismi, pastissi ja refleksiivisyys, ovat menettäneet alkuperäisen kriittisen funktionsa: ne eivät enää kyseenalaista varhaisempia, vallinneita representaation tapoja, vaan ovat itse tulleet vallitsevaksi tavaksi kuvata maailmaa. (Mt., 88, 90-91.)

Metamodernismi sen sijaan huojuu ironian ja innostuksen, sarkasmin ja vilpittömyyden välillä (Akker \& Vermeulen 2017, 11). Modernin poliittis-eettisen sitoutuneisuuden ja postmodernin skeptisyyden ristivedossa se etsii totuutta, jota se ei koskaan usko löytävänsä (Vermeulen \& van den Akker 2010). Näin se voi suhtautua kriittisesti suuriin kertomuksiin, kuten utopioihin, mutta pitää niiden tavoittelua silti arvokkaana. Toisin sanoen, merkityksestä ja totuudesta voi puhua myös vilpittömästi, ei ainoastaan ironisoiden (Hallila 2019, 160). Jos ironia on takaovi, jonka kautta kaikesta vakavasta on mahdollista perääntyä, metamodernissa ristivedossa se paukahtelee kiinni.

Parhaan mahdollisen maailman metamoderni eetos pyrkii ylittämään postmodernin kyynisyyden, joka tiivistyy Aurelian ystäväpiirissä toistuvaan hokemaan "VMP", "[v]ittu mitä paskaa" (PMM, 12). Hokemalla lyödään alas kaikki, joka on liian "runollista, teeskentelevää" tai "mahtipontista" (PMM, 7). Tyttärensä kuvitelmissa Theo kehottaa vakavuuteen: "Taiteilijoiden pitää anastaa juhlallisuus takaisin [terroristeilta ja sotaretoriikalta]. Mene suin päin korkeinta säveltä kohti, Aurelia.” (PMM, 324.) Aurelia kuvittelee isän neuvovan häntä vaikeuksissa olevan teatteriproduktion kanssa, mutta Theon kehotuksen voi lukea myös metafiktiivisenä kommenttina romaanin huojuntaan pateettisuuden ja kyyni-

syyden välillä. Samansuuntaisesti lapsuuden traumaansa muisteleva Joachim kannustaa itseään: "[U]skalla tuoda sen viattomuus ja vilpittömyys näyttämölle sitten kun on sen aika" (PMM, 205).

Parhaassa mahdollisessa maailmassa teatterin "[n]äyttämö on vaihtoehtoisten historioiden paikka" (PMM, 64), dialektinen areena, jolla historian voimia tör- 
mäytetään toisiinsa. Joachimin näytelmän aihe on "Berliinin muurin viimeiset päivät, kaikki se mikä tapahtui ja sekin mikä olisi voinut tapahtua" (PMM, 10). Näyttämöllä Aurelia kokee voimakkaimmin, kuinka eri aikatasot vuotavat toisiinsa, ja tuntee kuolleiden siskojen läsnäolon. Lavasteet vertautuvat filosofiseen koneistoon: "suuria fasadeja, kaikenlaista välineistöä jolla liikutellaan kokonaisia aikakausia, pyöräytetään maailmankäsityksiä ympäri vain yhtä nappia painamalla" (PMM, 162).

Jo Aurelian ja Joachimin ensimmäinen keskustelu ilmentää teatterin metamodernia eetosta ja utooppista virettä. Aurelia on kuullut "raitiovaunussa kahden juopon yhteiskuntakriittisen keskustelun", jossa Suomea oli moitittu "atopiaksi" (PMM, 13). Joachim keksii sille sosiologisen määritelmän: "Eräänlainen epäpaikka. Sellainen jossa on mahdotonta löytää kohtaansa suhteessa toisiin, itseen ja maailmaan.” (PMM, 13.) Vermeulen ja van den Akker määrittelevät atopoksen aika-avaruudeksi, jonka kautta metamodernismi ilmaisee itseään. Se on eräänlaista välitilaa tai välissä olemista, jolle on ominaista tietoinen pyrkimys ajan ja paikan ylittämiseen ja samalla tietoisuus tuon pyrkimyksen mahdottomuudesta. Se huojuu modernin utooppisen ja postmodernin dystooppisen ilmaisun välillä. (Vermeulen \& van den Akker 2010.) Näin siinä voi etsiä "suhdetta toisiin, itseen ja maailmaan", vaikka tietää, että lopullinen totuus tulee aina pakenemaan etsijäänsä.

Näyttelijäntyötään Aurelia kuvaa utooppisena pyrkimyksenä löytää jotain universaalia epäpaikkaisuudesta huolimatta: "Ei ole mitään minää. On vain läsnäolo joka kokoaa kaikkien kivut ja naurun ja historian ja haaveet huomisesta yhteen [--]." (PMM, 13.) Joachim vastaa Aurelialle naurulla, jonka "tarkoitus oli yhtä aikaa sekä kunnioittaa Aurelian mahtipontisuutta että kyseenalaistaa se" (PMM, 14) - metamodernisti toivon ja skeptisyyden välillä huojuen. Mika Hallila (2019) tarkastelee Asko Sahlbergin romaania Yö nielee päivät (2014) metamodernin teorian valossa. Hän tulkitsee metamodernin subjektin olevan "kuin näyttelijä”, joka edustaa lannistumatonta ihmisyyttä (Hallila 2019, 174). Samaan tapaan Aurelian voi nähdä edustavan metamodernia subjektia, joka lannistumatta pitää kiinni tulevaisuuden haaveista, vaikka se edellyttää välillä näyttelemistä. Näin hän toteuttaa metamodernia "ikään kuin" -logiikkaa (ks. Hallila 2019, 159), jossa hän kulkee kohti haaveita ikään kuin ne olisivat toteutettavissa.

Näytelmässä pyritään kokonaiskuvaan Berliinin muurin murtumisesta, historiallisen totaliteetin tavoittamiseen. Tässä mielessä se on sukua jamesonilaiselle kognitiiviselle kartoitukselle, pyrkimykselle representoida totaliteetti eli globaali maailmanjärjestelmä kokonaisuudessaan tiedostaen samalla, että sen representointi on viime kädessä mahdotonta (ks. Jameson 1992, 409). Representaation mahdottomuuteen kytkeytyy myös historian kriisi postmodernissa kirjallisuudessa, joka ei kykene representoimaan menneisyyttä vaan ainoastaan historian simulacrumin: historiamme kulttuurisen kuvaston, jonka heijastamme Platonin luolan seinälle (Jameson 1992, 25). Ylittämätön muuri onkin näytelmän keskeinen motiivi, jonka kautta historian totaliteettia pyritään esit- 
tämään. Näytelmän työryhmä käy läpi erilaisia vaihtoehtoja, joilla muuri voitaisiin toteuttaa: valoilla, betonilla, näyttelijöiden muodostamilla ketjuilla. Lopulta representaatio epäonnistuu ja Joachim toteaa: "[M]eidän on vain myönnettävä, ettemme me saa niitä [suuria teemoja] näyttämölle. Meillä ei ole tapaa toteuttaa niitä." (PMM, 315.)

Vasta kun representaation mahdottomuus on tiedostettu, avautuu mahdollisuus läpimurtoon. Viimeisessä yrityksessä lavalle tuodaan vesiallas, jonka yli Aurelian on määrä uida. Sukeltaessaan pinnan alle hän tiedostaa kuolleen kaksoissiskonsa läsnäolon ja trauma alkaa purkautua. Romaanin epilogissa näytelmä on vihdoin saanut ensi-iltansa ja lavalla on ainoastaan Aurelia, joka nyt toimii kertojana: "Olen näyttämö, ja täällä, lempeässä hämärässä, asiat ovat kaiken aikaa meneillään kaikkina aikakausina. Sitä ei voi käsittää järjellä, pitää ajatella ajan sisäkkäisyyksiä ja hiukan kuvitella [--].” (PMM, 353.) Näyttämöllä on "koko historia" (PMM, 353). Historian totaliteetti on siis läsnä, mutta vain kuvitteellisena. "Kaikki on mahdollista" (PM, 354), Aurelia toteaa. Toteamus on vastalause väitteelle, että maailma, jossa elämme, on paras mahdollinen. Samalla Aurelian kuolleelle isälleen osoittamat sanat kertovat, että utopia on representoimattomissa: "Isä, kerro meille korkeimmasta sävelestä! Kerro meille siitä mitä näet! Nyt sinulla on käsitys kaikesta, viimeinkin! Mutta isän ääni loittonee, puhe käy turhaksi juuri kun hän on kertomaisillaan [--].” (PMM, 355.) Metamodernismissa utopiaa tavoitellaan, vaikkei sitä uskota saavutettavan.

Eurooppalaisten unien viimeinen luku on kyberpunk-vaikutteinen dystopia tulevaisuuden globaalista hyperkapitalismista. Jameson (1992, 38, 321) näkee kyberpunkin ylikansallisten yritysten todellisuuden, globaalin vainoharhaisuuden ja representaatioiden ylikuluttamisen kiteyttävänä lajina. Immi Rahim, yksi romaanin keskushenkilöistä, työskentelee lontoolaisyritys Magicorpissa. Se on teknologisesti edistynyt ja vaikutusvaltainen viestintätoimisto, joka luo asiakkailleen hyödyllistä julkisuutta keksittyjen tai vääristeltyjen uutisten avulla. Valeuutiset auttavat niitä, joilla on varaa maksaa yrityksen palveluksista: valtioita, diktaattoreita ja suuryrityksiä. Immi yrittää perustella itselleen, ettei hänen työnsä valeuutisten käsikirjoittajana muuta mitään, sillä totuutta ei voi lopulta tietää: "Mistä saattoi ikinä tietää mikä on totta, jokin uutinen saattoi olla lavastettu alun perin tai monisyisestä tarinasta oli unohtunut kaksi kolmasosaa, ei tilanne ole mihinkään muuttunut" (EU, 161).

Immin kriittisyys työantajaansa ja vallitsevaa järjestelmää kohtaan voimistuu vähitellen. Hän ei osaa perustella työtään äidilleen, joka "ei ymmärtänyt nykymaailman pintaluonnetta" (EU, 165) eli sen postmodernia simulacrumia. "Me ollaan eri todellisuuksissa joka tapauksessa, todellisuus on valintaa ja kertomuksia joka tapauksessa, JA on parempi että ihmisille valitaan vähän parempi maailma" (EU, 165). Utooppinen pyrkimys parhaaseen mahdolliseen maailmaan on hylätty, ja maailmoista erotellaan "vähän parempi" valitsemalla oikeat kertomukset. Äiti ei vakuutu vaan kehottaa Immiä lopettamaan työnsä. Keskustelun jälkeen Immi näkee Toman ja Johanneksen näyn toisinnon, "unia tunnelista, 
jossa ihmiset vaelsivat etsien pääsyä ulos” (EU, 166). Hän alkaa epäillä, että on "päätynyt uskomaan lumeeseen, pintaan, sellaiseen mikä näyttää joltakin mutta ei oikeasti ole sitä" (EU, 166).

Värähtely epäilyksen ja toiveikkuuden välillä, itsekriittinen optimismi, on teoksen metamodernistisen eetoksen ytimessä. Immi värvää opiskeluaikaisen ystävänsä Pekan ja laulajatähti Eline van der Leyn utooppiseen projektiin, joka etsii vaihtoehtoa vallitsevalle yhteiskuntajärjestelmälle. "Me halutaan käsikirjoittaa toinen maailma" (EU, 172), Immi sanoo. Projektissa Immi hyödyntää Magicorpissa oppimaansa informaatiovaikuttamista ja ryhtyy Pekan kanssa kirjoittamaan "pakoreittiä" tai "tunnelia" (EU, 169), jonka kautta utooppinen vaihtoehto avautuisi. Eline on hankkeen keulakuva, ja Immin on määrä kaapata Magicorpin propagandakoneisto käyttöönsä ja levittää sen kautta hankkeen video maailmalle. Kolmikko on tietoinen hankkeensa naiivista toiveikkuudesta, mutta myös tarpeesta toteuttaa se: he ovat "hulluja" ja "tampioita", mutta "[u]topian ajatteleminen tuntui vain pakottavalta" (EU, 175).

Lopussa Eurooppalaisten unien ontologinen rakenne alkaa avautua. Immi nukahtaa ja näkee unen "siitä miten kaikki tapahtuu" (EU, 176). Unta kuvataan kappaleen verran, mutta kun siirrytään seuraavaan kohtaukseen, on epäselvää, ollaanko vielä Immin unessa vai onko hän herännyt. Tällä ontologisella tasolla kolmikon utooppinen hanke onnistuu yli odotusten. Toisen maailman kirjoittaminen on aiheuttanut jonkinlaisen poikkeaman aika-avaruudessa, ja Immi alkaa saada puhelimeensa viestejä menneisyydestä ihmisiltä, jotka lupaavat osallistua muutokseen. Romaanissa nähdyt uninäyt selittyvät nyt Immin ja Pekan käsikirjoituksen aiheuttamina muutoksina historian kudoksessa. McHalen $(2003,90)$ mukaan postmodernille historialliselle romaanille tyypillisiä keinoja ovat apokryfinen historia, luova anakronismi ja historiallinen fantasia, joilla se pyrkii haastamaan niin virallisen historian kuin historiallisen fiktion konventiot. Eurooppalaisten unien ontologinen huojunta mukailee tätä postmodernia estetiikkaa, mutta samalla romaanin eetos pyrkii ylittämään postmodernin skeptisyyden ja avaamaan "tunnelin" utooppiseen ajatteluun. Se omii postmodernin konvention osaksi fiktiivistä ontologiaansa: romaanin maailmassa on mahdollista vaikuttaa menneisyyteen, ei ainoastaan ymmärrykseemme siitä.

\section{Lopuksi}

Eurooppalaiset unet ja Paras mahdollinen maailma ovat esimerkkejä suomalaisen nykykirjallisuuden kehityskulusta, jossa painopiste siirtyy kansallista laajempaan viitekehykseen. Samalla ne ilmentävät ironian ja vilpittömyyden välillä huojuvaa eetosta, jonka selittämiseen postmodernismin teoriat eivät ole riittäviä. Niiden metamoderni utooppisuus näyttäytyy reaktiona uusliberalistisen toiveikkuuden aikakauden päättymiseen: kytkös markkinatalouden ja 
liberaalin demokratian välillä on osoittautunut löyhäksi ja globaalin kapitalismin ekologiset rajat alkavat tulla yhä selvemmin vastaan. Romaanien mukaan utooppista ajattelua tarvitaan, jotta nykyiselle järjestelmälle voidaan kuvitella vaihtoehtoja. Ne etualaistavat kysymyksen utopian representoinnista ja kuvittelusta: utooppisuus ei ole niiden piiloinen juonne vaan keskeinen teema. Kenties metamodernismi on siis kypsempää, itsetietoisempaa postmodernismia, erän̈laista globaalin kapitalismin kognitiivista kartoitusta (ks. Ojajärvi 2020, 67). Tällöin postmodernismin teesit, kuten suurten kertomusten kyseenalaistuminen, tiedon subjektiivisuus ja historiallisen käsityskyvyn hiipuminen, eivät enää ole oivaltavia tulkintoja nykykirjallisuudesta, joka on jo hyväksynyt ne lähtökohdikseen. Pikemmin on kysyttävä, miten nykykirjallisuus pyrkii elämään näiden lähtökohtien kanssa tai näkemään niiden tuolle puolen.

Puikkosen ja Pulkkisen romaanit epävakauttavat todellisuuden ja aikatasot. Ontologisen huojunnan taustalla ei ole postmoderni epäluulon eetos, joka pyrkisi osoittamaan historiallisen tiedon epävarmuuden tai herkistämään korvamme totuuksien ontolle kumulle. Ajan, paikan ja persoonan rajoja rikkomalla romaaneissa herätellään utooppista halua, joka on uinunut postmodernien vuosikymmenten antiutooppisessa ilmapiirissä. Samalla romaaneissa ollaan tietoisia pyrkimyksen idealismista ja epäillään sen onnistumisen mahdollisuutta.

Levitasin (2014, 18-19) mukaan utooppinen kuvittelu tapahtuukin aina mielikuvituksen ristipaineessa: sitä likistää se, mitä pystymme kuvittelemaan, ja se, mitä pystymme kuvittelemaan mahdolliseksi. Romaanien metamodernissa utooppisuudessa on oikeastaan kyse tilan avartamisesta ontologisen ja epistemologisen kuvittelun rajojen puristuksessa. Ontologisesti on kyse siitä, millaisen maailman pystymme kuvittelemaan, ja epistemologisesti siitä, miten voimme muuttaa tämän maailman toiseksi. Näitä rajoja ympäröivän toivottomuuden läpi metamoderni utooppisuus kaivaa tunneleitaan - laajentaa mahdollisen tajua (ks. Meretoja 2018, 9). Romaanit eivät ole utooppista kirjallisuutta siinä mielessä, että ne sisältäisivät suunnitelman tulevaisuuden yhteiskunnasta. Sen sijaan ne muistuttavat siitä, että toisenlaisten maailmojen kirjoittaminen on jälleen välttämätöntä. ${ }^{6}$

\section{Viitteet}

1 Ontologisesta huojunnasta sekä fiktiivisen ja aktuaalisen maailman viittaussuhteesta ks. esim. Ameel (2020) ja Westphal (2011, 108-110).

2 Käsite on alun perin Gary Saul Morsonilta (1994). Rinnakoinniksi sen on kääntänyt Matti Hyvärinen $(2007,133)$.

3 Väite epäpoliittisuudesta ei tietysti päde kategorisesti postmoderniin kirjallisuuteen, kuten ei antiutooppisuuskaan (ks. esim. Malmio 2019, 199-200; Kurikka 2005).

4 Jamesonin (1992) mukaan postmodernismi on simulacrumin kulttuuria, josta puuttuu syvyys ja historian taju. Guy Debordin (1983) spektaakkelin ajatusta hyödyntäen Jameson tarkoittaa simu- 
lacrumilla kulttuurin kaiken läpäisevää

kuvallistumista: kuvat eivät enää kykene representoimaan mitään alkuperäistä vaan viittaavat ainoastaan toisiin kuviin. (Mt., 6 ,

18.)

5 Konstantinou $(2017,88)$ ottaa esimerkeiksi muun muassa David Foster Wallacen,
Zadie Smithin, David Eggersin ja Jonathan Franzenin.

6 Artikkeli on kirjoitettu osana Suomen Kulttuurirahaston rahoittamaa tutkimushanketta "Sodanjälkeisen Euroopan historia ja metamodernismi suomalaisessa nykykirjallisuudessa."

\section{Aineisto}

Puikkonen, Emma 2016. Eurooppalaiset unet [=EU]. Helsinki: WSOY.

Pulkkinen, Riikka 2016. Paras mahdollinen maailma [=PMM]. Helsinki: Otava.

\section{Kirjallisuus}

Akker, Robin van den \& Timotheus Vermeulen 2017. Periodising the 2000s, or, the Emergence of Metamodernism. Teoksessa Metamodernism. Historicity, Affect, and Depth After Postmodernism. Eds Robin van den Akker, Alison Gibbons \& Timotheus Vermeulen. London \& New York: Rowman \& Littlefield, 1-19.

Ameel, Lieven 2020. "A Geo-ontological Thump": Ontological Instability and the Folding City in Mikko Rimminen's Early Prose. Teoksessa Contemporary Nordic Literature and Spatiality. Eds Kirstina Malmio \& Kaisa Kurikka. New York: Palgrave Macmillan, 211-230. https://doi. org/10.1007/978-3-030-23353-2_10

Boxall, Peter 2013. Twenty-First-Century Fiction. A Critical Introduction. New York: Cambridge University Press . https://doi.org/10.1017/CBO9780511902727

Debord, Guy 1983. Society of the Spectacle. Detroit: Black \& Red.

Fukuyama, Francis 1992. Historian loppu ja viimeinen ihminen. (The End of History and the Last Man, 1992.) Suom. Heikki Eskelinen. Helsinki: WSOY.

Gibbons, Alison 2020. Metamodernism, the Anthropocene, and the Resurgence of Historicity: Ben Lerner's 10:04 and "The Utopian Climmer of Fiction". Critique: Studies in Contemporary Fiction. https://doi.org/10.1080/00111619.2020.1784828

Hallila, Mika 2019. Lannistumattoman ihmisyyden aika. Asko Sahlbergin Yö nielee päivät ja metamodernismin etiikka. Teoksessa Muistikirja ja matkalaukku. Muotoja ja merkityksiä 2000-luvun suomalaisessa romaanissa. Toim. Elina Arminen \& Markku Lehtimäki. Helsinki: SKS, 153-176.

Helle, Anna 2019. Postmodernismista metamodernismiin? Esimerkkinä Eino Santasen kokoelmat Tekniikan maailmatja Yleisö. Joutsen 2019: Kotimaisen kirjallisuudentutkimuksen vuosikirja. Toim. Vesa Haapala \& Päivi Koivisto. Helsinki: Helsingin yliopisto, 51-67. https://doi.org/10.33346/ joutsen-svanen.90997

Huber, Irmtraud 2014. Literature after Postmodernism: Reconstructive Fantasies. Houndmills, Basingstoke, Hampshire \& New York: Palgrave Macmillan.

Hyvärinen, Matti 2007. Kertomus ja kertomuksen rajat. Puhe ja kieli 27(3), 127-140.

Hägg, Samuli 2000. Suomalaisen postmodernismikeskustelun jäljillä. Teoksessa Rajatapauksia. Kirjallisuudentutkijain Seuran vuosikirja 53. Toim. Mika Hallila \& Tellervo Krogerus. Helsinki: SKS, 102-107. 
Isomaa, Saija \& Toni Lahtinen (toim.) 2017. Pakkovaltiosta ekodystopiaan. Kotimainen nykydystopia. Helsinki: Helsingin yliopisto.

Jameson, Fredric 1982. Progress versus Utopia; Or, Can We Imagine the Future? Science Fiction Studies 9(2), 147-158.

—1992 (1991). Postmodernism, or, The Cultural Logic of Late Capitalism. London \& New York: Verso.

-2007. Archaeologies of the Future: The Desire Called Utopia and Other Science Fictions. London: Verso.

Konstantinou, Lee 2017. Four Faces of Postirony. Teoksessa Metamodernism. Historicity, Affect, and Depth After Postmodernism. Eds Robin van den Akker, Alison Cibbons \& Timotheus Vermeulen. London \& New York: Rowman \& Littlefield, 87-102.

Kurikka, Kaisa 2005. Tytöksi-tulemisen tilat. Monika Fagerholmin Diva utopistisena tekstinä. Teoksessa PoMon tila. Kirjoituksia kirjallisuuden postmodernismista. Toim. Anna Helle \& Katriina Kajannes. Jyväskylä: Kampus Kustannus, 56-72.

Leibniz Cottfried W. 1996. Theodicy: Essays on the Coodness of Cod, the Freedom of Man and the Origin of Evil. Ed. Austin Farrer, trans. E. M. Huggard. La Salle, IL: Open Court.

Levitas, Ruth 2011 (1990). The Concept of Utopia. Oxford: Peter Lang. https://doi. org/10.3726/978-3-0353-0010-9

—2014 (2013). Utopia as Method: The Imaginary Reconstitution of Society. New York: Palgrave Macmillan.

Lyotard, Jean-François 1985. Tieto postmodernissa yhteiskunnassa (La Condition postmoderne: Rapport sur le savoir, 1979.) Suom. Leevi Lehto. Tampere: Vastapaino.

Malmio, Kristina 2019. Vanhat ja uudet leikit. Postmodernismi ja sen "yli" kirjoittaminen 2000luvun suomenruotsalaisissa romaaneissa. Teoksessa Muistikirja ja matkalaukku. Muotoja ja merkityksiä 2000-luvun suomalaisessa romaanissa. Toim. Elina Arminen \& Markku Lehtimäki. Helsinki: SKS, 177-210.

McHale, Brian 2003 (1987). Postmodernist Fiction. London \& New York: Routledge. https://doi. org/10.4324/9780203393321

McGuigan, Jim 2006. Modernity and Postmodern Culture. Second Edition. Berkshire \& New York: Open University Press.

Meretoja, Hanna 2018. Kertomusten eettinen potentiaali ja vaarat: kuusi mittapuuta. Avain 2018(1), 6-25. https://doi.org/10.30665/av.70005

Morson, Gary Saul 1994. Narrative and Freedom: The Shadow of Time. New Haven \& London: Yale University Press.

Niemi, Juhani. 2019. Ajan ja paikan rajoja murtamassa. Suomalaisen nykyromaanin globaalistuminen. Teoksessa Muistikirja ja matkalaukku. Muotoja ja merkityksiä 2000-luvun suomalaisessa romaanissa. Toim. Elina Arminen \& Markku Lehtimäki. Helsinki: SKS, 66-97.

Nissilä, Hanna-Leena 2017. Ylirajainen kirjallisuus ja yksikielinen kirjallinen elämä Suomessa. Kulttuuripolitiikan Tutkimuksen Vuosikirja, 67-79. https://doi.org/10.17409/kpt.60105

Ojajärvi, Jussi 2020. Glokaali nykyromaani postmodernismin tällä puolen. Avain 17(1), 66-68. https://doi.org/10.30665/av.89700

Sandbacka, Kasimir 2017. Metamodernism in Liksom's Compartment No. 6. CLCWeb: Comparative Literature and Culture 19(1). https://doi.org/10.7771/1481-4374.2891

Vermeulen, Timotheus \& Robin van den Akker 2010. Notes on Metamodernism. Journal of Aesthetics \& Culture, 2010(2). https://doi.org/10.3402/jac.v2io.5677

-2015. Utopia, Sort of: A Case Study in Metamodernism. Studia Neophilologica 87(1), 55-67. https:// doi.org/10.1080/00393274.2014.981964

Westphal, Bertrand 2011. Ceocriticism: Real and Fictional Spaces. Trans. Robert T. Tally. New York: Palgrave Macmillan. 